\title{
Building Pathfinders with Free Screen Capture Tools
}

This article outlines freely available screen capturing tools, covering their benefits and drawbacks as well as their potential applications. In discussing these tools, the author illustrates how they can be used to build pathfinding tutorials for users and how these tutorials can be shared with users. The author notes that the availability of these screen capturing tools at no cost, coupled with their ease of use, provides ample opportunity for low-stakes experimentation from library staff in building dynamic pathfinders to promote the discovery of library resources.

O ne of the goals related to discovery in the University of Nevada Las Vegas (UNLV) Libraries' strategic plan is to "expand user awareness of library resources, services and staff expertise through promotion and technology." ${ }^{11}$ Screencasting videos and screenshots can be used effectively to show users how to access materials using finding tools in a systematic, step-by-step way. Screencasting and screen capturing tools are becoming more intuitive to learn and use and can be downloaded for free. As such, these tools are becoming an efficient and effective method for building pathfinders for users. One such tool is Jing (http:/ / www.jingproject.com), freeware that is easy to download and use. Jing allows for short screencasts of five minutes or less to be created and uploaded to a remote server on Screencast.com. Once a Jing screencast is uploaded, Screencast.com provides a URL for the screencast that can be shared via e-mail or instant message or on a webpage. Another function of Jing is recording screenshots, which can be annotated and shared by URL or pasted into documents or presentations. Jing serves as an effective tool for enabling librarians working with students via chat or instant messaging to quickly create screenshots and videos that visually demonstrate to students how to get the information they need. Jing stores the screenshots and videos on its server, which allows those files to be reused in subject or course guides and in course management systems, course syllabi, and library instructional handouts. Moreover, Jing's files storage provides an opportunity for librarians to incorporate tutorials into a variety of spaces where patrons may need them in such a manner that does not require internal library server space or work from internal library Web specialists.

Trailfire (http:/ / www.trailfire.com) is another screencapturing tool that can be utilized in the same manner. Trailfire allows users to create a trail of webpage

Patrick Griffis (patrick.griffis@unlv.edu) is Business Librarian, University of Nevada Las Vegas Libraries. screenshots that can be annotated with notes and shared with others via a URL. Such trails can provide users with a step-by-step slideshow outlining how to obtain specific resources. When a trail is created with Trailfire, a URL is provided to share. Like Jing, Trailfire is free to download and easy to learn and use.

Wink (http://debugmode.com/wink) was originally created for producing software tutorials, which makes it well suited for creating tutorials about how to use databases. Although Wink is much less sophisticated than expensive software packages, it can capture screenshots, add explanation boxes, buttons, titles, and voice to your tutorials. Screenshots are captured automatically as you use your computer on the basis of mouse and keyboard input. Wink files can be converted into very compressed Flash presentations and a wide range of other file types, such as PDF, but do not support AVI files. As such, Wink tutorials converted to Flash have a fluid movie feel similar to Jing screencasts, but Wink tutorials also can be converted to more static formats like PDF, which provides added flexibility.

SlideShare (http:/ / www.slideshare.net) allows for the conversion of uploaded PowerPoint, OpenOffice, or PDF files into online flash movies. An option to sync audio to the slides is available, and widgets can be created to embed slideshows onto websites, blogs, subject guides, or even social networking sites.

Any of these tools can be utilized for just-in-time virtual reference questions in addition to the common use of just-in-case instructional tutorials. Such just-in-time screen capturing and screencasting offer a viable solution for providing more equitable service and teachable moments within virtual reference applications. These tools allow library staff to answer patron questions via e-mail and chat reference in a manner that allows patrons to see processes for obtaining information sources. Demonstrations that are typically provided in face-toface reference interactions and classroom instruction sessions can be provided to patrons virtually. The efficiency of this practice is that it is simpler and faster to capture and share a screencast tutorial when answering virtual reference questions than to explain complex processes in written form. Additionally, the fact that these tools are freely available and easy to use provides library staff the opportunity to pursue low-stakes experimentation with screen capturing and screencasting.

The primary drawback to these freely available tools is that none of them provides a screencast that allows for both voice and text annotations, unlike commercial products such as Camtasia and Captivate. However, tutorials rendered with these freely available tools can be repurposed into a tutorial within commercial applications like Camtasia Studio (http://www.techsmith.com/camtasia .asp) and Adobe Captivate (http://www.adobe.com/ products/captivate/). 
As previously mentioned, these easy-to-use tools can allow screencast videos and screenshots to be integrated into a variety of online spaces. A particularly effective type of online space for potential integration of such screencast videos and screenshots are library "how do I find . . ." research help guides. Many of these "how do I find . . ." research help guides serve as pathfinders for patrons, outlining processes for obtaining information sources. Currently, many of these pathfinders are in text form, and experimentation with the tools outlined in this article can empower library staff to enhance their own pathfinders with screencast videos and screenshot tutorials.

\section{Reference}

1. “UNLV Libraries Strategic Plan 2009-2011," http:/ /www .library.unlv.edu/about/strategic_plan09-11.pdf (accessed July 30, 2009): 2.

UNLV Special Collections continued from page 186

\section{References}

1. Peter Michel, "Dino at the Sands," UNLV Special Collections, http://www.library.unlv.edu/speccol/dino/index.html (accessed July 28, 2009).

2. PeterMichel, “UNLVSpecialCollectionsSearchBox.”UNLV Special Collections. http://www.library.unlv.edu/speccol/ index.html (accessed July 28, 2009).

3. UNLV Special Collections search results, "Hoover Dam," http://www.library.unlv.edu/speccol/databases/index .php?search_query=hoover+dam\&btS=Search\&cols[]=oh\&cols []= man\&cols[] = photocoll\&act $=2$ (accessed October 27, 2009).

4. UNLV Libraries, "Southern Nevada: The Boomtown Years," http://digital.library.unlv.edu/boomtown/ (accessed July 28, 2009)
5. UNLV Special Collections, "What's New in Special Collections," http://blogs.library.unlv.edu/whats_new_in_special_ collections / (accessed July 28, 2009).

6. UNLV Special Collections, "UNLV Special Collections Facebook Homepage," http://www.facebook.com/home .php?\#/pages/Las-Vegas-NV/UNLV-Special-Collections/70053 571047? ref=search (accessed July 28, 2009).

7. UNLV Libraries, "Comments Section for the Aerial View of Hughes Aircraft Plant Photograph," http://digital.library .unlv.edu/hughes/dm.php/hughes/82 (accessed July 28, 2009); UNLV Libraries, "'Rate It' feature for the Aerial View of Hughes Aircraft Plant Photograph," http://digital.library.unlv.edu/ hughes/dm.php/hughes/82 (accessed July 28, 2009); UNLV Libraries, "RSS feature for the index to the Welcome Home Howard Digital Collection" http:/ /digital.library.unlv.edu/hughes/ dm.php/ (accessed July 28, 2009).

\section{STATEMENT OF OWNERSHIP, MANAGEMENT, AND CIRCULATION}

Information Technology and Libraries, Publication No. 280-800, is published quarterly in March, June, September, and December by the Library Information and Technology Association, American Library Association, 50 E. Huron St., Chicago, Illinois 60611-2795. Editor: Marc Truitt, Associate Director, Information Technology Resources and Services, University of Alberta, K Adams/Cameron Library and Services, University of Alberta, Edmonton, AB T6G 2J8 Canada. Annual subscription price, \$65. Printed in U.S.A. with periodical-class postage paid at Chicago, Illinois, and other locations. As a nonprofit organization authorized to mail at special rates (DMM Section 424.12 only), the purpose, function, and nonprofit status for federal income tax purposes have not changed during the preceding twelve months.

\section{EXTENT AND NATURE OF CIRCULATION}

(Average figures denote the average number of copies printed each issue during the preceding twelve months; actual figures denote actual number of copies of single issue published nearest to filing date: September 2009 issue). Total number of copies printed: average, 5,096; actual, 4,751. Mailed outside country paid subscriptions: average, 4,090; actual, 3,778. Sales through dealers and carriers, street vendors, and counter sales: average, 430; actual 399. Total paid distribution: average, 4,520; actual, 4,177. Free or nominal rate copies mailed at other classes through the USPS: average, 54; actual, 57. Free distribution outside the mail (total): average, 127; actual, 123. Total free or nominal rate distribution: average, 181; actual, 180. Total distribution: average, 4,701; actual, 4,357. Office use, leftover, unaccounted, spoiled after printing: average, 395; actual, 394. Total: average, 5,096; actual, 4,751. Percentage paid: average, 96.15; actual, 95.87.

Statement of Ownership, Management, and Circulation (PS Form 3526, September 2007) filed with the United States Post Office Postmaster in Chicago, October 1, 2009. 